\title{
BAPETEN SUPERVISORY AUTHORITY IN THE PROCEDURE OF TRANSPORTATION OF RADIOACTIVE SUBSTANCE THROUGH THE SEA
}

\author{
Shinta Hadiyantina ${ }^{1}$; Dewi Cahyandari ${ }^{2}$; Dhiana Puspitawati ${ }^{3}$ \\ 1,2,3Faculty of Law, Universitas Brawijaya \\ Email: shinta_fh@ub.ac.id; dhiana@ub.ac.id
}

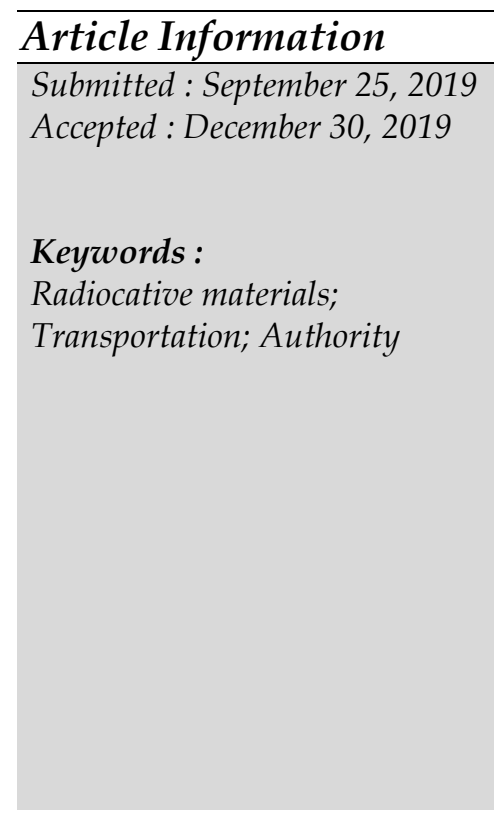

\begin{abstract}
One important thing that must be considered in the use of nuclear and other radioactive materials is the process of transporting radioactive substances through the sea. This paper will analyze the optimization of the supervisory authority of BAPETEN in the transportation of radioactive substances, especially in the process of transporting radioactive substances by sea. Option to choose the sea because most of Indonesia's territory is the sea. If it has the authority, Bapeten's supervisory authority will then be analyzed in the process of transporting radioactive substances via the sea lane. Recommendations from this article are a form of juridical liability if an error occurs, which causes a loss in the process of transporting radioactive substances by sea. Because the process of transporting radioactive substances is essential in preventing the occurrence of radiation, the regulatory authority in the transportation process must be regulated in detail based on the precautionary principle, as well as the form of juridical accountability.
\end{abstract}

\section{Introduction}

Radioactive material is very potent energy. One of the radioactive substances that are very useful for people's lives is nuclear. In some developed countries, nuclear power has been utilized in various fields of public life, such as in the fields of research, agriculture, health, industry and energy. However, despite the enormous benefits, nuclear power also has the potential for radiation hazards both to living things and the environment around them. Therefore, the provisions regarding nuclear safety starting from the process of exploration, exploitation, transport and utilization must be well formulated. One example of the potential danger posed by nuclear power is the Chernobyl disaster and the Fukushima disaster. The two incidents were nuclear incidents which reached a scale of 7 on the INES scale. As mentioned earlier, in the utilization of nuclear energy, the precautionary principle must be highly considered, especially during the process of transporting the radioactive material. Although there are many modes of transportation, more nuclear transportation is still carried out by air and by sea.

In the case of nuclear transportation by sea, the 1982 Sea Law Convention (KHL 1982) regulates nuclear transportation in Article 22 and Article 23 in the regulation on the right of innocent passage. In general, foreign ship crossings in the territorial sea do not require a permit from a coastal country, as long as the passage is carried out in accordance with the provisions on the right of innocent passage in Article $19 \mathrm{KHL}$

Yustisia Volume 8 Number 3 (Sept.-Dec. 2019)

BAPETEN Supervisory Authority...

(C)2019; This is an Open Acces Research distributed under the term of the Creative Commons Attribution Licencee (https://Creativecommons.org/licences/by/4.0), which permits unrestricted use, distribution, and reproduction in any medium, provided the original works is properly cited. 
1982 and the crossing can be carried out anywhere in the territorial sea. However, specifically for nuclear-powered ships as well as ships carrying nuclear right of innocent passage can only be done in specific sea lanes determined by the coastal states. Article 22 paragraph (2) of the 1982 KHL further stipulates that ships carrying radioactive material including nuclear must limit their voyages to specific channels designated by the coastal state, even in the territorial sea. Furthermore, such ships must equip themselves with documents determined by both the coastal country and the country of origin of the radioactive material, as well as observing and adhering to the precautionary principle as determined in international law. Government Regulation No. 58 of 2015 about Radiation Safety and Security in Transporting Active Radio Substances, also regulates the transport of radioactive substances. Transport of Radioactive Substances is the removal of radioactive substances that fulfil the technical requirements of Radiation Safety in the Transport of Radioactive Substances and technical Security in Transportation of Radioactive Substances, from one place to another through public traffic networks, using land, water, or air transportation.

The implementation, of course Indonesia as the country with the largest sea area in the world, must also pay attention to the provisions of the $1982 \mathrm{KHL}$, moreover nuclear transport is mostly done by sea. Although the use of nuclear power has not been widespread in Indonesia, the use of nuclear power in Indonesia has been regulated in several legal provisions. Regulations related to nuclear power are regulated in Act Number 10 of 1997 on Nuclear Energy. Before Law Number 10 of 1997 on Nuclear Energy was in force, the applicable Law was Law Number 31 of 1964 on the Basic Atomic Energy Provisions.

One of the essential processes in nuclear utilization is the transportation process. The transportation process is essential to be regulated by the government because of the radiation hazards that are feared can threaten the safety of workers, the public, and also the environment from radiation hazards during transportation of radioactive substances. This transportation process is regulated in Government Regulation No. 58 of 2015 on Radiation Safety and Security in Transporting Radioactive Substances. While the agency authorized to conduct oversight of the use of nuclear power in Indonesia is carried out by the Nuclear Energy Supervisory Agency (BAPETEN). Unfortunately, BAPETEN function as regulated in Article 3 of Presidential Decree Number 76 of 1998 on the Nuclear Energy Supervisory Agency does not regulate the supervisory function.

This paper will analyze the supervisory authority of BAPETEN in the transportation of radioactive substances, especially in the process of transporting radioactive substances. If it has the authority, Bapeten's supervisory authority will be analyzed in the process of transporting the radioactive material. Furthermore, it will be recommended a form of juridical liability if an error occurs, which causes a loss in the process of transporting radioactive substances. Because the process of transporting radioactive substances is vital in preventing the occurrence of radiation, the supervisory authority in the transportation process must be regulated in detail as well as the form of juridical accountability.

\section{Research MethodS}

The research method with a normative juridical approach, prioritizes library research and its implementation in practice. Research specifications are descriptive. The research 
phase is carried out through library research, collecting secondary data in the form of primary, secondary, and field research materials to obtain primary data as a support.

\section{Research Result and Discussion}

\section{A. Theory of Authority and Supervisory Theory}

The terms power, authority and competence, are often simply equated. The terms authority and power are often exchanged. Power has the meaning of the rule and the ruled (those who rule and those who are ruled) (Miriam Budiardjo, 1998: 3536). Based on the above understanding, power can occur that has nothing to do with the law. Henc van Maarseven called blote match (Suwoto Mulyosudarmo, 1990: 30), as a power that has nothing to do with the law while according to Max Weber, the power that has to do with law is called rational or legal competence. Rational/legal competence is a competence based on a legal system that is recognized and adhered to by the community, also the rules are strengthened by the state.

In public law, power is related to competence (Philipus M. Hadjon, 1998: 1). Power and competence have the same meaning. The power and competence inherent in the legislative, executive and judiciary are formal powers. Power is the main element in the process of governance, the other elements are (Rusady Kantaprawira, 1998: 37-38):

1. Law;

2. Authority (competence);

3. Policy;

4. Justice;

5. And honesty.

According to Miriam Budiardjo, power is the ability to influence the behaviour of others to follow the goals of their desires (Miriam Budiardjo, 1998: 35). To exercise power, a ruler or agency is needed. The state is conceived as a set of een ambten complex (positions) by a number of officials based on the construction of subjectobligations (Rusady Kantaprawira, 1998: 39). Thus, power has two aspects, namely political and legal aspects, whereas authority is only a legal aspect. Power can come from the constitution or outside the constitution, for example, through a coup or war, while the authority comes from the constitution.

Authority is formal power derived from legislative power (by law) or derived from administrative executive power. Authority is power over a field of government by a particular group of people (Prajudi, 1998: 78). Ateng Syafrudin believes there is a difference between the notion of authority and competence (Ateng Syafrudin, 1995: 22). Authority is formal power that comes from legislation and competence is part of that authority. Competence is in the scope of public law, talking about government decisions and also the implementation of the tasks set in the legislation. Juridically, competence has the meaning of ability that comes from legislation and causes legal consequences (Indroharto, 1994: 65). According to H.D. Stoud, authority briefly is all the rules regarding the use by the government as a subject of public law. 
In connection with the source of legislative competence, Indroharto outlines as below (Indroharto, 1999: 15):

1. Attribution

Attribution is the delegation of a new governmental competence by a provision in the legislation.

2. Delegation

Delegation is the delegation of competence that already exists by a state administrative agency or position that has obtained attributive legislative competence to another state administrative agency or position.

Sub delegation

Sub delegation is a delegation of government competence that has been obtained by delegates to other officials that must be determined in the legislation.

3. Mandate

The mandate is the implementation of authority possessed by mandans to mandates that are internal relations of government. Outgoing responsibility remains with the mandan because there has not been a devolution of authority. The competence of the government is implemented by mandates on behalf of and mandates responsibility.

The mandate of non-subordinates is the implementation of authority by officials who are not hierarchically under the mandans. This can be done if the following conditions are met:

1) Mandates are willing to accept the mandate given.

2) The Mandated competence includes the daily competence of the mandate.

3) The relevant legislations do not oppose the form of mandating.

Supervision is an activity that is very important so that the work and tasks assigned to the implementation apparatus are carried out in accordance with the established plan. This is in accordance with the opinion of Sondang P. Siagian who stated that supervision is a process of observation rather than the implementation of all the activities of the organization to ensure that all work being carried out goes according to a predetermined plan (Sondang Siagian, 2000: 135).

According to Sujamto, supervision is any effort or activity to know and evaluate the facts of the implementation of a task or activity, whether or not it is appropriate (Sujamto, 1990: 17). The definition of supervision emphasizes a process of supervision running systematically in accordance with the stages that have been determined. In Indonesian dictionary the term "Supervision comes from the word alert which means to pay attention, in the sense of looking at something carefully and thorough, there is no more activity except to give a report based on the actual reality of what is being watched" (Sujanto, 1986: 2 ). If we pay further attention, the main problem of the intended supervision is a plan that has been outlined in advance whether it has been carried out in accordance with the original plan and whether the objectives have been 
achieved. The supervisory function is an activity carried out by the leader or an organ in observing, comparing the tasks or work that is distinguished to the implementing apparatus with established standards, reinforcing a sense of responsibility to prevent irregularities and correct errors in the implementation of work.

Basically, every policy carried out by the leader of an organ has specific functions that are expected to be carried out, in line with the objectives of the policy. Likewise, the implementation of supervision in a work environment or a particular organization. Supervision carried out has a function in accordance with its objectives. Regarding this matter, Soerwarno Handayanigrat stated that there were matters relating to the supervisory function, namely:

a. strengthen the sense of responsibility towards officials who are entrusted with duties and authority in carrying out their work;

b. educate officials so that they carry out work in accordance with established procedures;

c. to prevent irregularities, neglect, and weaknesses so that undesirable losses do not occur;

d. to correct mistakes and misuse so that the implementation of the work does not experience obstacles and waste.

\section{B. Constitutional Rights of Citizens and Regulations on the Use of Radioactive Materials in Indonesia}

Supervision of BAPETEN in the procedure for transporting radioactive substances by sea is one of the steps to fulfil the constitutional rights of citizens, which are listed in the 1945 Constitution of the Republic of Indonesia, particularly the right to personal, family, honour, dignity, and property under his authority (Article 28G paragraph (1)) and the right to a good and healthy environment (Article $28 \mathrm{H}(1))$. Supervision by BAPETEN is an effort to preserve the environment so that there is no nuclear disaster in the process of transportation by sea. In addition, the surveillance effort aims to protect all citizens from the nuclear disaster in the process of transporting by sea.Since the birth of the Unitary State of the Republic of Indonesia (NKRI/Negara Kesatuan Republik Indonesia) in 1945, the state has upheld the implementation of Human Rights. This appears from the Pancasila and the 1945 Constitution, which contains several provisions concerning respect for the human rights of citizens. So that in the practice of state administration, the protection or guarantee of human rights and citizens' rights or the constitutional rights of citizens can be implemented. The 1945 Constitution has granted 40 constitutional rights to all Indonesian citizens. National Women's Commission compiles 40 constitutional rights into 14 groups.

Regulations related to nuclear power are regulated in Law Number 10 of 1997 on the Nuclear Power (Law 10/2997). Before Law Number 10 of 1997 on the Nuclear Energy was in effect, the applicable Law was Law Number 31 of 1964 on the Basic Atomic Energy Provisions. The development of the times and the advancement of science and technology in the use of nuclear power have resulted in many provisions 
in the law that are no longer appropriate, for example, the authority to carry out and supervise research and use of nuclear power given in one body so that the oversight function is not optimal. In addition, nuclear materials must be owned and controlled by the state, while the sale and purchase of these materials have been carried out internationally so that the requirements that must be owned by the state will hamper the development of the use of nuclear power. However, the requirements that must be controlled by the state are maintained because, despite the international free trade in nuclear materials, the Government is still required to conduct surveillance so that there is no deviation from the intended use of nuclear materials. Therefore, it is deemed necessary to make new law on nuclear power to replace Law Number 31 of 1964 on Basic Atomic Energy Provisions.

Regarding the problem of transporting radioactive material, Law 10/1997 regulates it in Article 16, which stipulates that every activity related to nuclear utilization is obliged to pay attention to safety, security and peace, the health of workers and members of the public, and protection of the environment. The provisions referred to in Article 16 paragraph (1) is regulated further in a Government Regulation. At present, the Government Regulation referred to in Article 16 paragraph (1) is Government Regulation Number 58 of 2015 (PP 58/2015).

Regarding of Government Regulation Number 58 of 2015 on Radiation Safety and Security in Transporting Radiocative Substance, it regulates two things, which are related to safety and security. What is meant by the transportation of radioactive substances is the transfer of radioactive substances that meet the technical requirements for radiation safety in the transportation of radioactive substances and the technical security of transporting radioactive substances, from one place to another through army's tool, water, or air. Safety and security have a different understanding. Radiation Safety in Transporting Radioactive Substances is an action taken to protect workers, members of civilians, and the environment from radiation hazards during the Transportation of Radioactive Substances. Security in Transporting Radioactive Substances is an action taken to prevent attempts at theft, sabotage, illegal transfer, and other unlawful acts against radioactive substances during the Transportation of Radioactive Substances.

This Government Regulation consists of 8 chapters, which regulates: 1) General Provisions; 2) Types of Radioactive Substances; 3) Radiation Safety Technical in Transporting RadioactiveSubstances; 4) Technical Safety in Transporting Radioactive Substances; 5) Radiation Safety Management in the Removal of Radioactive Substances and Security in Transportation of Radioactive Substances; 6) Emergency Preparedness and Management System in Transporting Radioactive Substances; 7) Management of Transportation of Radioactive Substances; 8) Administrative Sanctions; 9) Transitional Provisions; 10) Final Provisions.

Management of the transport of radioactive substances is regulated in Government Regulation No. 58 of 2015 about Radiation Safety and Security in the Transport of Radioactive Substances Article 80 to Article 81. If described in the schematic, the management procedures for transporting radioactive substances are as follows: 
The first step that must be taken is the sender submits a written application to the Head of BAPETEN. The Head of BAPETEN will assess the written request within three working days. If the written application is approved, the Head of BAPETEN will issue an approval for the delivery of radioactive substances. The legal consequences of the agreement are the obligation to carry out transport of radioactive materials in accordance with the obligations stated in the agreement on the delivery of radioactive substances and laws and regulations; and submit a written report to the Head of BAPETEN regarding the implementation of the Transport of Radioactive Substances.

Government Regulation Number 58 of 2015 is a substitute government regulation of Government Regulation Number 26 of 2002 on Safety of Transporting Radioactive Substances. Government Regulation No. 26/2002 on Safety of Transporting Radioactive Substances is a substitute government regulation on Government Regulation No. 13/1975 about the Transport of Radioactive Substances.

Chapter III PP 58/2015 regulates the technical safety of radiation in the transport of radioactive substances. If the technical requirements have been fulfilled, a certificate will be issued by BAPETEN. The certificate can be regarded as one of the licensing documents of the transport of radioactive substances. Nirwono explained that the granting of a permit in the form of a certificate could be said to be a form of supervision conducted by BAPETEN.

Although the rule in government regulation is very technical and has strict sanctions, unfortunately, the particular handling of safety is not distinguished based on the transportation mode used. Of course, such transportation can be done by land, sea, and air. Even modes of the sea and air transportation are more often used in the transport of radioactive substances. For land transportation, the land transportation service still adheres to Law Number 22 Of 2009 about Traffic and Transportation, especially in the task of supervising road transport for hazardous substances (B3), but technical guidelines governing the transport of radioactive substances via roads not available. Violations of these articles will be subject to the highest administrative sanctions, namely the revocation of permits. However, there is no single article governing the supervision carried out in the transportation process.

Likewise, the transportation of radioactive substances by sea and air. For air transportation media, aviation safety and security aspects have been regulated in Act Number 1 of 2009 about Aviation. However, there are no specific provisions regarding the safety and security of transportingradioactive substances. Nevertheless, BAPETEN has begun to coordinate with the directorate of air transportation. Furthermore, for sea transportation, as explained in the background, the underlying legal instruments are still in the provisions of KHL 1982. Although BAPETEN has also coordinated with the Badan Kemanan Laut (BAKAMLA) for supervision during the sea transportation process, it is essential to remember that different with the land, and the sea area consists of various zones wherein each zone the authority of the coastal states varies. Thus institutions related to supervision and legal meaning will also be different. It also has not been stated in the form of the rule of law. 


\section{BAPETEN is a Supervisory Body Supervising All Nuclear Power Surveillance Activities:}

BAPETEN is a Supervisory Body formed by the government which is tasked with supervising all nuclear power surveillance activities. The legal basis is Article 4 of Law 10/1997, which stipulates that the Government will establish a Regulatory Body that is tasked with supervising all nuclear power utilization activities. The regulatory body administers regulations, permits, and inspections.

BAPETEN is authorized to:

1. Arranging national macro plans in their fields;

2. Formulation of policies in their fields to support macro development;

3. Determination of accreditation and certification requirements in their fields;

4. Other authorities in accordance with the provisions of the applicable laws and regulations, namely:

a. formulation and implementation of specific policies in the field of nuclear power supervision;

b. the formulation of policies for supervising the use of high technology that is strategic in its field;

c. the stipulation of guidelines for supervision over the utilization of nuclear power;

d. guaranteeing the welfare, security, and security of the people from nuclear hazards;

e. guaranteeing the safety and health of workers and members of the civilians and protecting the environment from nuclear hazards;

f. prevention of changes in the purpose of the use of nuclear materials.

The implementation of Article 4 is contained in Presidential Decree Number 76 of 1998 about the Nuclear Energy Supervisory Agency (BAPETEN). Article 2 of Keppres 76/1998 regulates the task of BAPETEN to carry out the supervision use of nuclear power in Indonesia.

Article 3 Keppres 76/1998 further stipulates that to carry out its duties as stipulated in Article 2 of Keppres 76/1998, BAPETEN carries out the following functions:

a. formulation of national policies in the field of supervision of the use of nuclear power;

b. compilation of national plans and programs in the field of supervision over the use of nuclear power;

c. fostering and drafting regulations and carrying out assessments of nuclear safety, radiation safety, and security of nuclear materials;

d. implementation of licensing and inspection of the construction and operation of nuclear reactors, nuclear installations, nuclear material facilities, and sources of radiation as well as the development of nuclear preparedness;

e. implementation of cooperation in the field of supervision over the use 
of nuclear power with Government agencies or other organizations both inside and outside the territory of Indonesia;

f. implementation of supervision and control of nuclear materials;

g. implementation of safety and counselling towards efforts related to the safety and health of workers, members of civilian and protection of the environment;

h. implementation of human resource development within the BAPETEN environment;

i. implementation of administrative guidance, control, and supervision within BAPETEN;

j. implementation of other tasks given by the President

Although points $\mathrm{d}$, e and $\mathrm{f}$ have control points, it is not clear whether the intended control includes supervision in transportation. Even though the inspection function has an inspection function, it is not clear whether the inspection is only during the use of radioactive substances or is included in the transportation process. The Presidential Decree also did not explain how the supervision mechanism carried out by BAPETEN, especially in the process of transporting radioactive substances.

The transportation process that has a high risk should be closely monitored, but it is unfortunate that both PP 58/2015 and Keppres 76/1998 do not provide the authority to supervise. From the background that has been described, the authors compile research with the title Existence of BAPETEN in Supervision of Transport Procedures for Radioactive Substances.

Normatively, BAPETEN has used its authority to make implementing regulations related to the transport of radioactive substances. Namely the Decree of the Head of the Nuclear Power Supervisory Agency Number 04 / Ka-BAPETEN / V-99 (Keputusan Kepala Badan Pengawas Tenaga Nuklir Nomor 04/Ka-BAPETEN/V-99) on Safety Provisions for the Transport of Radioactive Substances. However, this regulation also has a constraint, namely all Government Regulations listed in the consideration are no longer valid. The legal basis for the Decree of the Head of Bapeten include:

1. Law Number 10 of 1997;

2. Government Regulation Number 11 Of 1997;

3. Government Regulation Number 12 of 1997;

4. Government Regulation Number 13 of 1997;

5. Republic of Indonesia's Presidential Decree Number 76 of 1998;

6. Republic of Indonesia's Presidential Decree No. 161 / M / 1998;

7. Decree of the Head of the Nuclear Power Supervisory Agency Number 01 / K-OTK / VIII-98.

Government Regulation No. 11/1997 regulates work safety. This regulation has been changed twice, through Government Regulation Number 63 Of 2000 
and Government Regulation Number 33 Of 2007. The Government Regulation concerning work safety that is in effect, for now, is Government Regulation Number 33 Of 2007 on Ionizing Radiation Safety and Radioactive Source Security.

Government Regulation No. 12 of 1997 regulates permits for the use of radioactive substances or other radiation sources. This Government Regulation has been changed twice, through Government Regulation Number 43 of 2006 and Government Regulation Number 2 of 2014. Government Regulations in force, for now, are Government Regulation Number 2 of 2014 on Nuclear Installation Licensing and Nuclear Material Utilization.

Government Regulation No. 13 of 1997 regulates the safety of transporting radioactive substances. This government regulation has been changed twice, through Government Regulation Number 26 of 2002 and Government Regulation Number 58 of 2015. The applicable Government Regulation is Government Regulation Number 58 of 2015 on Radiation Safety and Security in the Transport of Radioactive Substances.

The problem in the decision of the head of BAPETEN is regulatory updates absences, even though the legal basis has been changed twice. The age of this regulation is 21 years old, and it is felt that the content of the material should have been adjusted in several sections.

Law Number 10 of 1997 regulates in regards to institutional matters, and there are two institutions, the implementing agency for the utilization of nuclear power and the supervision institution for nuclear utilization. The implementing agency above is the National Nuclear Energy Agency (BATAN/Badan Tenaga Nuklir Nasional). This is in accordance with Article 3 paragraph (1) of Law 10 of 1997 which states that "the government forms an Implementing Body which is under and directly responsible to the President, who is trying to provide nuclear power resources." As for the supervisory institution, as described previously is BAPETEN. Thus it is clear that the actual authority in BAPETEN is Attribution authority, which is the authority obtained from the Law.

In juridical normative, supervision of nuclear utilization, the UUK orders the making of implementing regulations as stated in Articles 16, 17, 18, 27, and 34. As mentioned above, BAPETEN as the Supervisory Agency carries out supervision through regulations, permits, and inspections (Article 14). The objectives of supervision are to:

a. guarantee the welfare, security, and peace of society;

b. ensure the safety and health of workers and members of the civilian and protection of the environment;

c. maintain lawful order in the use of nuclear power;

d. increase legal awareness of the use of nuclear power to foster safety culture in the nuclear field;

e. prevent changes in the purpose of nuclear power utilization, and; 
f. ensure the maintenance and improvement of staff discipline in the use of nuclear power.

When viewed in detail, objectives supervision appear to be broad enough, so that what is carried out later by the Supervisory Agency is in accordance with that provision.

The first is safety, nuclear power is indeed useful, but its use must still maintain the safety of workers, the community and the environment. If these requirements are not met, then licensing will not be granted, because supervision is carried out using a licensing system. The second is security issues, the safety factor for the use of nuclear power. Namely radioactive substances, nuclear materials and installations used should be managed, protected physically so as not to fall into the hands of other people who are not entitled or so as not to be sabotaged. This factor seems to be the object of regulation in the Nuclear Security Bill (RUU Kemanan Nuklir) currently being prepared by the relevant agencies. The third is that the problem is preventing changes in the use of nuclear power. It means that the use of nuclear weapons, tools or installations must not be changed to make nuclear weapons. For this technical term that is commonly used internationally is safeguard. Safeguard to achieve this goal has long been carried out since the formation of the International Atomic Energy Agency (IAEA) in 1957. US President Eisenhower's famous statement "Atom for Peace" emphasizes that the use of atomic energy is only for peaceful purposes. If not, then the race to make nuclear weapons can bring destruction to humanity.

If BAPETEN wants to partner with BAKAMLA in regards to land and air transportation, then it is questionable whether those institutions invited to cooperate with BAPETEN can have supervisory authority. Here it is worth remembering that the authority of attribution can be reduced to the authority of the delegation if it is still within an institution that is hierarchically under the institution that provides the delegation. While the mandate, although there is no delegation of authority, it can only be done in internal government relations where there is no hierarchical relationship between the mandate and the mandan.

Thus, if BAPETEN wants to check the authority for BAKAMLA or the Land Transportation and Air Control Agency in the form of radioactive, that can be done through the provision of a supervisory mandate in the process of transporting radioactive substances. Nevertheless, all those who are protected by their supervision, especially in the process of transportation must be stated in the form of legal instruments. Legal instruments can thus be transferred in a Technical Directive or Technical Guidelines or even a Joint Decree.

\section{Conclusion}

Even though Indonesia already has a legal framework relating to the use of nuclear power, there are still many legal instruments that must be formed to support the responsible use of radioactive substances. One of them is about the supervisory authority 
of BAPETEN, especially in the process of transportation at sea. A fundamental process in the use of radioactive substances. Transport of radioactive substances can be through land, air or sea transportation modes. Because the legal regime that applies between land, air, and the sea is very different, primarily if transportation is carried out by the sea. Therefore, it is necessary to regulate the supervisory function of BAPETEN in each mode of transportation. It is necessary to formulate a legal instrument that regulates in detail the mechanism of supervision and the granting of the supervisory authority in a particular legal instrument. Such legal instruments can be outlined in the form of a Joint Decree.

\section{BIBLIOGRAPHY}

\section{Books:}

Miriam Budiardjo. (1998). Dasar-Dasar Ilmu Politik. Jakarta: Gramedia Pustaka Utama.

Suwoto Mulyosudarmo. (1990). Kekuasaan dan Tanggung Jawab Presiden Republik Indonesia: Suatu Penelitian Segi-Segi Teoritik dan Yuridis Pertanggungjawaban Kekuasaan. Surabaya: Universitas Airlangga.

Rusadi Kantaprawira. (1998). Hukum dan Kekuasaan, Makalah. Yogyakarta: Universitas Islam Indonesia.

Prajudi Atmosudirdjo. Hukum Administrasi Negara. Jakarta: Ghalia Indonesia.

Indroharto. (1994). Asas-Asas Umum Pemerintahan yang Baik, dalam Paulus Efendie Lotulung, Himpunan Makalah Asas-Asas Umum Pemerintahan yang Baik. Bandung: Citra Aditya Bakti.

Indroharto. (1999). Usaha Memahami UU PTUN (buku 1) Beberapa Pengertian Dasar Hukum Tata Usaha Negara. Jakarta: Sinar Harapan.

Siagian, Sondang. P. (2000). Administrasi Pembangunan. Jakarta: Gunung Agung.

Sujamto. (1990). Otonomi Daerah yang Nyata dan Bertanggung Jawab. Jakarta: Sinar Grafika.

Sujanto. (1986). Beberapa Pengertian di Bidang Pengawasan. Jakarta: Ghalia Indonesia.

\section{Articles/Journals/Proceeding:}

Philipus M Hadjon, Tentang Wewenang, Makalah, Universitas Airlangga, Surabaya

Ateng Syafrudin. (2009). Menuju Penyelenggaraan Pemerintahan Negara yang Bersih dan Bertanggungjawab. Jurnal Pro Justicia Fourth Edition. Universitas Parahyangan

Nirwono, Muttaqin Margo. “Reviu Pengaturan Pengangkutan Zat Radioaktif di Indonesia," Prosiding Seminar Keselamatan Nuklir, 5-6 Agustus 2009

Yusri Heni N.A., Suhartono Zahir2, Amil Mardha. Peranan Konvensi Keselamatan Nuklir dalam Upaya Peningkatan Keselamatan PLTN Secara Global. Seminar Keselamatan Nuklir 2 - 3 Agustus 2006

Widya Krulinasari. (2013). Pengaturan Hukum Internasional Terhadap Penggunaan Nuklir untuk Tujuan Damai. Fiat Justitia Jurnal Ilmu Hukum Volume 7 Number. 


\section{Legal Documents:}

United Nation Convention on The Law of The Sea 1982

Law Number 10 of 1997 on The Nuclear Power.

Government Regulation Number 58 of 2015 on the Radiation Safety and Security in Transporting Radiocative Substance

Presidential Decree Number 76 of 1998 on the Nuclear Energy Regulation Agency (BAPETEN)

\section{Websites:}

Rakor Pembinaan Teknis Pengangkutan Zat Radioaktif, https:/ /www.bapeten.go.id/ berita/ rakor-pembinaan--teknis-pengangkutan--zat-radioaktif-085148 